ISSN 1678-3921

Journal homepage: www.embrapa.br/pab

For manuscript submission and journal contents, access: www.scielo.br/pab
Márcio Vieira da Cunha(1) (D),

Mércia Virginia Ferreira dos Santos ${ }^{(1)}$ (iD), Aurielle Silva Medeiros ${ }^{(1 \bowtie)}(\mathbb{D}$, Joelma de Lira Freire ${ }^{(1)}$ (iD, José Carlos Batista Dubeux Junior(2) (iD, Alexandre Carneiro Leão de Mello(1) (iD) and Carolina Câmara Lira(3) (iD

(1) Universidade Federal Rural de Pernambuco, Departamento de Zootecnia, Rua Manuel de Medeiros, s/non, Dois Irmãos, CEP 51171-900 Recife, PE, Brazil.

E-mail: marcio.cunha@ufrpe.br, mercia.vfsantos@ufrpe.br, aurielle.medeiros@ufrpe.br, freirejlf@yahoo.com.br, alexandre.Imello@ufrpe.br

(2) University of Florida, North Florida Research \& Education Center, 3925 FL-71, Greenwood, 32443 Marianna, FL, USA. E-mail: dubeux@ufl.edu

(3) Universidade Federal Rural de Pernambuco, Colégio Agrícola Dom Agostinho Ikas, Avenida Dr. Francisco Corrêa, no 643, Centro, CEP 54735-000 São Lourenço da Mata, PE, Brazil.

E-mail: camaralira@gmail.com

$\bowtie$ Corresponding author

Received

April 23, 2020

Accepted

February 22, 2021

How to cite

CUNHA, M.V. da; SANTOS, M.V.F. dos; MEDEIROS, A.S.; FREIRE, J. de L.; DUBEUX JUNIOR, J.C.B.; MELLO, A.C.L. de; LIRA, C.C. Repeatability and divergence among genotypes of Desmanthus sp. in a semiarid region. Pesquisa Agropecuária Brasileira, v.56, e01937, 2021. DOI: https://doi.org/10.1590/ S1678-3921.pab2021.v56.01937.

\section{Repeatability and divergence among genotypes of Desmanthus sp. in a semiarid region}

\begin{abstract}
The objective of this work was to evaluate the divergence among genotypes of Desmanthus sp. regarding morphological, productive, and qualitative characteristics, as well as to estimate the number of observations necessary to predict the real value of these characteristics. The experiment was conducted in the semiarid of the state of Pernambuco, Brazil, using 26 genotypes of Desmanthus sp. from different locations in the region. Seven evaluations were carried out from July 2013 to July 2014. Tocher's grouping method and standardized average Euclidean distance were used. The coefficients of repeatability ( $\mathrm{r}$ ) and determination $\left(\mathrm{R}^{2}\right)$ were estimated using two models of the analysis of variance, principal components based on the correlation or covariance matrix, and structural analysis based on the correlation matrix. The variables with the greatest weights were stem diameter, leaf area index, and forage yield, with frequencies of $22.05,17.57$, and $14.58 \%$, respectively. Morphological, productive, and qualitative variability was observed among the genotypes of Desmanthus sp. All characteristics presented $r$ and $\mathrm{R}^{2}$ of high magnitude in the methods of analysis. Up to four evaluation cycles are required to predict $\left(\mathrm{R}^{2}=95 \%\right)$ the real value of stem diameter, peduncle length, plant height, leaf length and width, number of leaves, and pod length.
\end{abstract}

Index terms: forage, native legume, plant breeding.

Repetibilidade e divergência entre genótipos de Desmanthus sp. em região semiárida

Resumo - O objetivo deste trabalho foi avaliar a divergência entre genótipos de Desmanthus sp. quanto a características morfológicas, produtiva e qualitativa, bem como estimar o número de observações necessárias para predizer o valor real destas características. $\mathrm{O}$ experimento foi conduzido no semiárido do estado de Pernambuco, Brasil, com uso de 26 genótipos de Desmanthus sp. de diferentes localidades nessa região. Foram realizadas sete avaliações de julho de 2013 a julho de 2014. Utilizou-se o método de agrupamento de Tocher e a distância euclidiana média padronizada. Os coeficientes de repetibilidade ( $\mathrm{r}$ ) e determinação $\left(\mathrm{R}^{2}\right)$ foram estimados por dois modelos de análise de variância, componentes principais baseados na matriz de correlação ou covariância, e análise estrutural baseada na matriz de correlação. As variáveis com maiores pesos foram diâmetro do caule (DC), índice de área foliar e produção de forragem, com frequências de 22,05, 17,57 e 14,58\%, respectivamente. Observou-se variabilidade morfológica, produtiva e qualitativa entre os genótipos de Desmanthus sp. Todas as características apresentaram $\mathrm{r}$ e $\mathrm{R}^{2}$ de alta magnitude nos métodos de análise. Até quatro ciclos de avaliação são necessários para prever $\left(\mathrm{R}^{2}=95 \%\right)$ o valor real de diâmetro do caule, comprimento do pedúnculo, altura da planta, comprimento e largura da folha, número de folhas e comprimento da vagem.

Termos para indexação: forrageira, leguminosa nativa, melhoramento de plantas. 


\section{Introduction}

The Desmanthus genus is composed of 24 legume species naturally distributed in tropical and subtropical regions of the Americas (Muir et al., 2014). However, the genus also occurs naturally in other edaphoclimatic conditions around the world (Sonawane et al., 2019; Patil et al., 2020), such as in the Brazilian semiarid (Costa et al., 2017; Muir et al., 2019). Legumes of the genus have shown potential to optimize animal production (Santos et al., 2019) and stand out as some of the few to adapt and persist under heavy grazing on clay soils in seasonally dry regions (Gardiner et al., 2013).

It should be noted that genotypes of Desmanthus may show variability regarding morphological, productive, and qualitative characteristics, as is the case of those collected in the Brazilian semiarid region (Calado et al., 2016; Diniz, 2016). Costa et al. (2017) found that the number of seeds was the morphological descriptor that contributed the most to characterize the genetic divergence among 26 Desmanthus genotypes.

Therefore, it is essential to expand knowledge on the variability of naturally occurring genotypes as the basis for future forage breeding programs, especially with native plants that still require additional information to improve the efficiency of their use. This is important since the genetic breeding of tropical forages is still a very recent activity compared with that of temperate forages (Jank et al., 2014). In addition, the gradual degradation process of Brazilian native biomes highlights the need to obtain more information on available plant genetic resources, an aspect of great interest for germplasm collection and assessment activities.

One of the complexities of forage breeding is related to the determination of the number of evaluations necessary to estimate, with accuracy, differences among the studied genotypes (Toebe et al., 2020). Using repeatability analysis, it is possible to determine the number of assessments required to predict the genotypic value of an individual along sequenced measurements throughout time (Chaves et al., 2018), obtaining predefined coefficients of determination (Cruz et al., 2014). These coefficients allow the reduction of the trial period, costs, and labor, optimizing the process for launching new cultivars (Torres et al., 2015; Rodrigues et al., 2020).

The objective of this work was to evaluate the divergence among genotypes of Desmanthus sp. regarding morphological, productive, and qualitative characteristics, as well as to estimate the number of observations necessary to predict the real value of these characteristics.

\section{Materials and Methods}

The research was carried out in Serra Talhada, a semiarid locality in the state of Pernambuco, Northeastern Brazil (07059'31"S, 38 $\left.17^{\prime} 54^{\prime \prime} \mathrm{W}\right)$. The average rainfall from planting in November 2011 until the last cut in July 2014 was $34.36 \mathrm{~mm}$ per month (Figure 1). The soil of the experimental area was classified as a Latossolo Vermelho-Amarelo (IUSS Working Group WRB, 2015), with the following physical-chemical characteristics in the 0 to $20 \mathrm{~cm}$ layer: $102.6 \mathrm{~g} \mathrm{~kg}^{-1}$ clay, $54.8 \mathrm{~g} \mathrm{~kg}^{-1}$ silt, $842.6 \mathrm{~g} \mathrm{~kg}^{-1}$ sand, pH 7.9 (water - 1.0:2.5), $348 \mathrm{mg} \mathrm{dm}{ }^{-3} \mathrm{P}, 0.39 \mathrm{cmol}_{\mathrm{c}} \mathrm{dm}^{-3}$ $\mathrm{K}, 0.48 \mathrm{cmol}_{\mathrm{c}} \mathrm{dm}^{-3} \mathrm{Na}, 3.2 \mathrm{cmol}_{\mathrm{c}} \mathrm{dm}^{-3} \mathrm{Ca}, 0.1 \mathrm{cmol}_{\mathrm{c}}$ $\mathrm{dm}^{-3} \mathrm{Mg}, 0.0 \mathrm{cmol}_{\mathrm{c}} \mathrm{dm}^{-3} \mathrm{Al}, 2.01 \mathrm{cmol}_{\mathrm{c}} \mathrm{dm}^{-3} \mathrm{H}+\mathrm{Al}, 19$ $\mathrm{g} \mathrm{kg}^{-1}$ organic carbon, and $33 \mathrm{~g} \mathrm{~kg}^{-1}$ organic matter.

The evaluated genotypes of Desmanthus sp. and their respective collection sites in the state of Pernambuco were: 25A in Serra Talhada; 92C, 100C, and 235C in the municipality of Sertânia; 65F, 89F, 94F, and 100F in the municipality of Bom Jardim; $15 \mathrm{~L}$ and $45 \mathrm{~L}$ in the municipality of Jataúba; and 11SA, 12SA, 13SA, 15SA, 16SA, 17SA, 19SA, 20SA, 21SA, 22SA, 23SA, 24SA, 27SA, 28SA, 29SA, and 39SA in the semiarid region. The active germplasm bank was formed in Serra Talhada by plants collected from April to August 2011 in different municipalities in the semiarid region of the state (Queiroz, 2012), and was maintained with sprinkler irrigation in the dry period, under $1.0 \mathrm{~m}$ spacing between rows and $0.5 \mathrm{~m}$ within rows, with the application of $0.5 \mathrm{~kg}$ organic fertilizer at the base of each pit at the time of planting.

In May 2013, the plants were staged at $40 \mathrm{~cm}$ in relation to the ground. From July 2013 to July 2014, evaluations were carried out at an interval of 60 days (seven evaluations), by measuring the following variables: plant height, stem diameter, leaf length and width, number of leaves, and peduncle (PEDL) and pod (PODL) lengths. Plant height, leaf length and width, PEDL, and PODL were evaluated with a measuring tape, whereas stem diameter was obtained with a caliper. 
In July 2014, the leaf area index (LAI) was measured using the LAI-2000 Plant Canopy Analyzer (LI-COR Inc., Lincoln, NE, USA). Forage yield (FY) was obtained by cutting the plants at $40 \mathrm{~cm}$ in relation to the ground. From the collected plant material, leaves and stems $(\varnothing \leq 5 \mathrm{~mm})$ were weighed and taken to a forcedair circulation oven, at $55 \pm 5^{\circ} \mathrm{C}$, until they reached a constant weight. The material was then weighed to determine dry weight and estimate the dry matter and crude protein $(\mathrm{CP})$ content of the forage according to the procedure described by Association of Official Agricultural Chemists International (Latimer Jr., 2016).

The data were subjected to the principal component analysis (Cruz, 2013). The standardized average Euclidean distance was calculated as a measure of dissimilarity, and genotype groups were formed using Tocher's grouping method. Repeatability coefficients were estimated based on five different methods described by Cruz et al. (2014): two models of the analysis of variance (ANOVA 1 and 2), principal component analysis (PCA) based on the correlation (PCACOR) or covariance (PCACOV) matrix, and structural analysis based on the correlation matrix (SACOR).
Using the ANOVA method, the repeatability coefficient was estimated with two models. The first was: $Y_{i j}=\mu+g_{i}+\varepsilon_{i j}$, where $Y_{i j}$ is the observation regarding the $i$-th environment (evaluation), $\mu$ is the overall mean, $g_{i}$ is the random effect of the $\mathrm{i}$-th genotype under the influence of the permanent environment $(i=1,2, \ldots, p)$, and $\varepsilon_{i j}$ is the effect of the temporary environment associated with the $\mathrm{j}$-th measurement on the $\mathrm{i}$-th genotype $\left(\mathrm{j}=1,2, \ldots, \eta_{\mathrm{i}}\right)$. The second was: $Y_{i j}=\mu+g_{i}+a_{j}+\varepsilon_{i j}$, where $Y_{i j}$ is the mean of the $i-t h$ genotype in the $j$-th cycle, $\mu$ is the overall mean of the experiment, $g_{i}$ is the effect of the $i$-th genotype under the influence of the permanent environment, $a_{j}$ is the a-th cycle effect, and $\varepsilon_{\mathrm{ij}}$ is the random error involving other causes of variation not included in the model. In these two models, the repeatability coefficient (r) for each characteristic was obtained by:

$$
r=\frac{\operatorname{Cov}\left(Y_{i j}, Y_{i j^{\prime}}\right)}{\sqrt{\widehat{V}}\left(Y_{i j}\right) \widehat{V}\left(Y_{i j^{\prime}}\right)}=\frac{\widehat{\sigma}_{g}^{2}}{\widehat{\sigma}_{Y}^{2}}=\frac{\widehat{\sigma}_{g}^{2}}{\hat{\sigma}^{2}+\widehat{\sigma}_{g}^{2}}
$$

In the PCACOR method, the repeatability estimate was calculated using the $\mathrm{R}$ correlation matrix. The repeatability coefficient $(r)$ was determined by: $\mathrm{r}=\left(\hat{\lambda}_{1}-\hat{\sigma}_{\mathrm{Y}}^{2}\right) /\left[\hat{\sigma}_{\mathrm{Y}}^{2}(\eta-1)\right]$, where $\hat{\lambda}_{1}$ is the largest eigenvalue obtained from ' $\Gamma$ ', associated with the

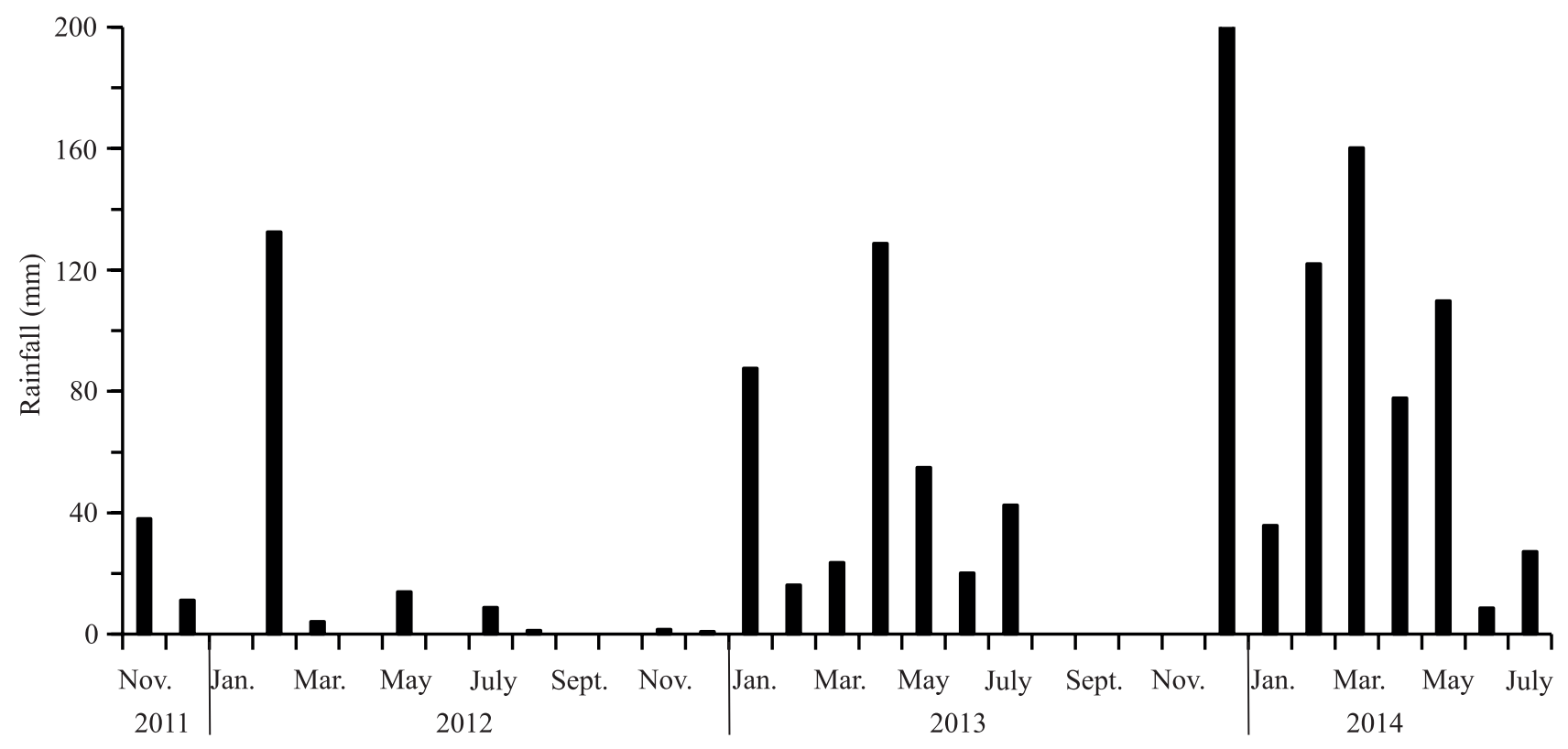

Experimental period (2011-2014)

Figure 1. Rainfall during the experimental period in the region of Serra Talhada, in the state of Pernambuco, Brazil. Source: APAC (2019). 
eigenvector whose elements have the same sign and similar magnitudes;

$$
\widehat{\sigma}_{\mathrm{Y}}^{2}=\frac{1}{\eta} \sum_{j} \hat{\sigma}_{\mathrm{j}}^{2}=\hat{\sigma}^{2}+\widehat{\sigma}_{\mathrm{g}}^{2}
$$

and $\eta$ is the number of evaluated cycles. In the SACOR method, the repeatability estimate was calculated using the $\mathrm{R}$ correlation matrix, as already shown, for each pair of measurements carried out in the different genotypes. The repeatability coefficient (r) was given by: $r=\left(\alpha^{\prime} \hat{R} \alpha-1\right) /(\eta-1)$ where $\hat{R}$ is the estimator of $\mathrm{R}$ and $\alpha^{\prime}=[1 / \sqrt{\eta \ldots 1} 1 / \sqrt{\eta}]$ is the auto vector with parametric elements associated with the largest eigenvalue of $\mathrm{R}$.

The estimate of the minimum number of measurements required to obtain the real value $\left(\eta_{0}\right)$ of the evaluated characteristics, based on preestablished coefficients of determination $(0.80,0.85$, 0.90 , and 0.95 ), was obtained through the expression: $\eta_{0}=\left[\mathrm{R}^{2}(1-\mathrm{r})\right] /\left[\left(1-\mathrm{R}^{2}\right) \mathrm{r}\right]$, where $\mathrm{R}^{2}$ is the coefficient of determination. Based on the mean of $\eta$ cycles $(\eta=7)$ and on the estimates of the repeatability coefficient according to the different methodologies used, the coefficient of determination $\left(\mathrm{R}^{2}\right)$ was calculated by the expression: $R^{2}=\eta \mathrm{r} /[1+\mathrm{r}(\eta-1)]$, where $\eta$ is the number of measurements required and $r$ is the repeatability coefficient. Principal component and repeatability analyses were performed using the GENES software (Cruz, 2013).

\section{Results and Discussion}

The accumulated variance in the principal components totaled $88.82 \%$ for the evaluated plants of the genus Desmanthus (Table 1). According to Cruz et al. (2014), the number of principal components to be

Table 1. Individual (Vi) and accumulated (Va) variances of the principal components on the ten evaluated descriptors in 26 genotypes of Desmanthus sp.

\begin{tabular}{lcc}
\hline Principal components & Vi (\%) & Va (\%) \\
\hline C1 & 22.05 & 22.05 \\
C2 & 17.57 & 39.62 \\
C3 & 14.58 & 54.20 \\
C4 & 11.56 & 65.76 \\
C5 & 9.79 & 75.55 \\
C6 & 7.72 & 83.27 \\
C7 & 5.55 & 88.82 \\
\hline
\end{tabular}

considered should explain at least $80 \%$ of the observed variation. This means that the first six principal components satisfactorily explained the variation among genotypes. The first two principal components were used, as they explained most $(39.62 \%)$ of the variation found in the original data.

When evaluated using the principal component analysis, the following variables carried the greatest weights: stem diameter, LAI, and forage yield, with frequencies of $22.05,17.57$, and $14.58 \%$, respectively. Stem diameter becomes important because it affects the transport of water and nutrients in the plant, whereas the LAI is a variable directly related to canopy photosynthesis and, consequently, to forage biomass (Edvan et al., 2016), which can affect animal performance.

Queiroz (2012) studied the environmental characteristics of different genotypes of Desmanthus sp. in the semiarid region of Pernambuco, but only observed the formation of three groups when using Tocher's grouping method. In the present study, nine distinct groups were formed with the 26 assessed genotypes of Desmanthus sp.: group 1, 11SA, 12SA, 15SA, 16SA, 22SA, 27SA, 39SA, 235C, and 100F; group 2, 17SA, 19SA, 20SA, 21SA, 28SA, 65F, and 25A; group 3, 13SA and 92C; group 4, 29SA and 94F; group 5, 23SA and 15L; group 6, 24SA; group 7, 89F; group $8,45 \mathrm{~L}$; and group $9,100 \mathrm{C}$. It is worth mentioning that the first two principal components explained only $39.62 \%$ of the data variation, a value lower than the $80 \%$ recommended by Cruz et al. (2014), which may influence the association of variables with groups.

The different groups formed characterize the genetic divergence among the genotypes of Desmanthus sp. However, in the present study, the majority of the genotypes (62\%) were found in the first two groups, implying that the genetic divergence among the genotypes was not high. Despite this, groups formed by isolated individuals (such as groups 6, 7, 8, and 9) presented the greatest divergence within the evaluated set; different genotypes for future recombination schemes can, therefore, be identified, facilitating the projection of breeding programs (Resende et al., 2014).

Group one, made up of the largest number of individuals, had an average forage yield of $81.25 \mathrm{~g}$ per plant, while group seven, with only the $89 \mathrm{~F}$ genotype, even with a lower plant height, had a forage yield of $222.70 \mathrm{~g}$ per plant (Table 2). However, group six 
(genotype 24SA) presented a LAI of 0.3 and a forage yield of $14.4 \mathrm{~g}$ per plant, lower than those of the other groups. In contrast, group nine (genotype 100C) had the greatest stem diameter of $3.0 \mathrm{~cm}$. The group that had the greatest forage yield (group 7) had the second highest crude protein (CP) content of $201 \mathrm{~g} \mathrm{~kg}^{-1}$, only below that of $212 \mathrm{~g} \mathrm{~kg}^{-1}$ of the genotypes in group 5 . The $201 \mathrm{~g} \mathrm{~kg}^{-1}$ value represents an increase of 17, 26, 41, 101, 41,18 , and $15 \%$ in CP over groups $1,2,3,4,6,8$, and 9 , respectively. These results highlight that the genetic divergence found among genotypes allows forage breeders to produce several alternative crossbreeds, while seeking to complement characteristics of interest in offspring, such as forage yield and CP content. The $\mathrm{CP}$ values reported here ranged from 100 to $212 \mathrm{~g} \mathrm{~kg}^{-1}$ dry matter (Table 2), being similar to that of $195 \mathrm{~g} \mathrm{~kg}^{-1}$ obtained by Patil et al. (2020). The higher content of CP observed in the present trial shows the great nutritional value of the plant and its potential for use in animal feed in tropical regions. It is worth mentioning that this legume persists and is selected by browsing animals, despite large forage mass fluctuations between rainy and dry seasons and browser preference (Santos et al., 2019).

According to Resende (2015), in the selection of a group of individuals, $\mathrm{R}^{2}$ values are considered adequate when they are above $80 \%$, whereas repeatability values are classified as low when below 0.30 , medium when between 0.30 and 0.60 , and elevated when above 0.60 . In general, it was found that, in the different methods used, all evaluated characteristics showed a high magnitude of repeatability and $\mathrm{R}^{2}$ (Table 3 ), which indicates that the mathematical models adopted were satisfactorily fitted to the data set. Furthermore, the high magnitude of these coefficients shows reliability in estimating the number of observations required to

Table 2. Means for stem diameter (SD), leaf area index (LAI), forage yield (FY), peduncle length (PEDL), crude protein (CP) content, plant height, leaf length (LL), leaf width (LW), number of leaves (NL), and pod length (PODL) of genotypes of Desmanthus sp. for the groups obtained by Tocher's grouping method.

\begin{tabular}{|c|c|c|c|c|c|c|c|c|c|}
\hline \multirow[t]{2}{*}{ Characteristic } & \multicolumn{9}{|c|}{ Group } \\
\hline & 1 & 2 & 3 & 4 & 5 & 6 & 7 & 8 & 9 \\
\hline Stem diameter $(\mathrm{SD}, \mathrm{cm})$ & 1.1 & 2.1 & 0.7 & 1.9 & 1.4 & 1.5 & 1.9 & 1.2 & 3.0 \\
\hline LAI & 1.2 & 0.9 & 1.6 & 3.2 & 1.4 & 0.3 & 1.0 & 0.3 & 1.4 \\
\hline Forage yield ( $\mathrm{g}$ per plant) & 81.2 & 98.2 & 160.3 & 214.7 & 115.2 & 14.4 & 222.7 & 31.1 & 172.3 \\
\hline PEDL $(\mathrm{cm})$ & 2.4 & 1.4 & 2.2 & 1.6 & 2.6 & 1.2 & 1.1 & 2.5 & 1.9 \\
\hline Crude protein $\left(\mathrm{CP}, \mathrm{g} \mathrm{kg}^{-1}\right)$ & 171 & 160 & 143 & 100 & 212 & 143 & 201 & 170 & 174 \\
\hline Plant height $(\mathrm{cm})$ & 53.5 & 53.7 & 46.0 & 55.5 & 60.5 & 64.0 & 40.1 & 46.0 & 65.4 \\
\hline Leaf length (LL, cm) & 5.0 & 5.6 & 5.5 & 5.0 & 5.5 & 4.5 & 7.1 & 9.2 & 9.1 \\
\hline Leaf width (LW, cm) & 5.9 & 4.6 & 3.6 & 6.4 & 5.0 & 3.8 & 4.4 & 6.3 & 5.5 \\
\hline Number of leaves (NL) & 9.0 & 5.8 & 6.5 & 6.0 & 10.1 & 13.0 & 7.0 & 11 & 6.0 \\
\hline Pod length (PODL, cm) & 7.6 & 4.4 & 7.5 & 7.0 & 4.5 & 6.0 & 6.0 & 6.3 & 6.5 \\
\hline
\end{tabular}

Table 3. Estimates of the coefficients of repeatability $(\mathrm{r})$ and determination $\left(\mathrm{R}^{2}, \%\right)$ for stem diameter (SD), peduncle length (PEDL), plant height, leaf length (LL), leaf width (LW), number of leaves (NL), and pod length (PODL) of 26 genotypes of Desmanthus sp. using five different methods.

\begin{tabular}{|c|c|c|c|c|c|c|c|c|c|c|c|c|c|c|}
\hline \multirow{2}{*}{ Method $^{(1)}$} & \multicolumn{2}{|c|}{ SD } & \multicolumn{2}{|c|}{ PEDL } & \multicolumn{2}{|c|}{ Height } & \multicolumn{2}{|c|}{ LL } & \multicolumn{2}{|c|}{ LW } & \multicolumn{2}{|c|}{$\mathrm{NL}$} & \multicolumn{2}{|c|}{ PODL } \\
\hline & $\mathrm{r}$ & $\mathrm{R}^{2}$ & $\mathrm{R}$ & $\mathrm{R}^{2}$ & $\mathrm{r}$ & $\mathrm{R}^{2}$ & $\mathrm{r}$ & $\mathrm{R}^{2}$ & $\mathrm{r}$ & $\mathrm{R}^{2}$ & $\mathrm{r}$ & $\mathrm{R}^{2}$ & $\mathrm{r}$ & $\mathrm{R}^{2}$ \\
\hline ANOVA 1 & 0.91 & 98.71 & 0.97 & 99.56 & 0.89 & 98.26 & 0.97 & 99.58 & 0.99 & 99.94 & 0.89 & 98.00 & 0.87 & 98.08 \\
\hline ANOVA 2 & 0.91 & 98.73 & 0.97 & 99.56 & 0.85 & 97.62 & 0.97 & 99.59 & 0.99 & 99.94 & 0.89 & 98.33 & 0.88 & 98.10 \\
\hline PCACOR & 0.92 & 98.87 & 0.97 & 99.62 & 0.89 & 98.37 & 0.97 & 99.60 & 0.99 & 99.94 & 0.89 & 98.38 & 0.88 & 98.11 \\
\hline PCACOV & 0.92 & 98.88 & 0.97 & 99.60 & 0.91 & 98.63 & 0.97 & 99.61 & 0.99 & 99.94 & 0.89 & 98.31 & 0.88 & 98.12 \\
\hline SACOR & 0.91 & 98.76 & 0.97 & 99.62 & 0.88 & 98.15 & 0.97 & 99.60 & 0.99 & 99.94 & 0.89 & 98.35 & 0.88 & 98.09 \\
\hline Mean & 0.91 & 98.79 & 0.97 & 99.59 & 0.88 & 98.21 & 0.97 & 99.60 & 0.99 & 99.94 & 0.89 & 98.27 & 0.88 & 98.10 \\
\hline
\end{tabular}

(1)ANOVA 1 and ANOVA 2, analysis of variance based on models 1 and 2, respectively; PCACOR and PCACOV, principal component analysis based on the correlation and covariance matrices, respectively; and SACOR, structural analysis based on the correlation matrix. 
predict the real value of the assessed characteristics (Rodrigues et al., 2020).

The expression of all variables showed high regularity between evaluations, and the values found in the present study indicate the proportion of the real value of each characteristic that was repeated throughout the assessments (Table 3). By increasing the number of measurements performed for a given variable, the temporary variance caused by the environment is reduced and, consequently, phenotypic variance is also reduced, optimizing the accuracy of the repeatability coefficient. However, when the temporary environmental variance is low and repeatability is high, the increase in the number of measurements carried out will add little to the inference of the individual genotypic value (Martuscello et al., 2015).
The estimates of the repeatability coefficient and $\mathrm{R}^{2}$ for each variable were almost always lower when obtained by the ANOVA methods than by the other methods used (Table 3). However, when determined by PCACOR and PCACOV, the estimates were always greater than or equal to the general average. This result is in alignment with those of Cruz et al. (2014), who suggested that the repeatability analysis can be more efficiently estimated by the principal component method and also concluded that the ANOVA method can, in some cases, lead to undersized estimates of the repeatability coefficient.

High repeatability coefficients are desired, because as the repeatability coefficient is increased, the number of evaluations necessary to predict the real value of an individual is reduced (Rodrigues et al., 2020). In the five methods evaluated, one assessment cycle would be

Table 4. Estimates of the number of measurements $(\eta)$ for stem diameter (SD), peduncle length (PEDL), plant height, leaf length (LL), leaf width (LW), number of leaves (NL), and pod length (PODL) of 26 genotypes of Desmanthus sp. using five different methods.

\begin{tabular}{|c|c|c|c|c|c|c|c|c|}
\hline Method $^{(1)}$ & $\mathrm{R}^{2}$ & SD & PEDL & Height & LL & LW & NL & PODL \\
\hline \multirow{5}{*}{ ANOVA 1} & 0.80 & 0.34 & 0.12 & 0.49 & 0.11 & 0.02 & 0.48 & 0.54 \\
\hline & 0.85 & 0.49 & 0.17 & 0.69 & 0.16 & 0.02 & 0.68 & 0.77 \\
\hline & 0.90 & 0.78 & 0.27 & 1.10 & 0.26 & 0.03 & 1.08 & 1.22 \\
\hline & 0.95 & 1.65 & 0.58 & 2.34 & 0.54 & 0.08 & 2.29 & 2.59 \\
\hline & 0.99 & 8.61 & 3.04 & 12.20 & 2.86 & 0.41 & 11.96 & 13.51 \\
\hline \multirow{5}{*}{ ANOVA 2} & 0.80 & 0.35 & 0.12 & 0.68 & 0.11 & 0.02 & 0.47 & 0.54 \\
\hline & 0.85 & 0.50 & 0.17 & 0.96 & 0.16 & 0.02 & 0.67 & 0.76 \\
\hline & 0.90 & 0.80 & 0.27 & 1.53 & 0.25 & 0.03 & 1.06 & 1.21 \\
\hline & 0.95 & 1.69 & 0.58 & 3.23 & 0.54 & 0.08 & 2.25 & 2.56 \\
\hline & 0.99 & 8.85 & 3.02 & 16.85 & 2.83 & 0.41 & 11.72 & 13.38 \\
\hline \multirow{5}{*}{ PCACOV } & 0.80 & 0.31 & 0.10 & 0.46 & 0.11 & 0.02 & 0.45 & 0.53 \\
\hline & 0.85 & 0.45 & 0.15 & 0.65 & 0.15 & 0.02 & 0.64 & 0.76 \\
\hline & 0.90 & 0.71 & 0.23 & 1.04 & 0.24 & 0.04 & 1.03 & 1.21 \\
\hline & 0.95 & 1.51 & 0.50 & 2.20 & 0.52 & 0.07 & 2.17 & 2.56 \\
\hline & 0.99 & 7.90 & 2.62 & 11.47 & 2.72 & 0.38 & 11.34 & 13.34 \\
\hline \multirow{5}{*}{ PCACOR } & 0.80 & 0.31 & 0.11 & 0.38 & 0.10 & 0.02 & 0.47 & 0.53 \\
\hline & 0.85 & 0.44 & 0.15 & 0.54 & 0.15 & 0.02 & 0.67 & 0.75 \\
\hline & 0.90 & 0.70 & 0.24 & 0.86 & 0.24 & 0.03 & 1.07 & 1.20 \\
\hline & 0.95 & 1.49 & 0.52 & 1.83 & 0.50 & 0.07 & 2.27 & 2.54 \\
\hline & 0.99 & 7.79 & 2.72 & 9.56 & 2.65 & 0.36 & 11.84 & 13.25 \\
\hline \multirow{5}{*}{ SACOR } & 0.80 & 0.35 & 0.10 & 0.52 & 0.11 & 0.02 & 0.46 & 0.54 \\
\hline & 0.85 & 0.49 & 0.15 & 0.74 & 0.15 & 0.02 & 0.66 & 0.77 \\
\hline & 0.90 & 0.78 & 0.24 & 1.18 & 0.24 & 0.04 & 1.05 & 1.22 \\
\hline & 0.95 & 1.66 & 0.50 & 2.49 & 0.52 & 0.07 & 2.21 & 2.58 \\
\hline & 0.99 & 8.67 & 2.63 & 13.01 & 2.72 & 0.38 & 11.55 & 13.44 \\
\hline
\end{tabular}

(1)ANOVA 1 and ANOVA 2, analysis of variance based on models 1 and 2, respectively; PCACOR and PCACOV, principal component analysis based on the correlation and covariance matrices, respectively; and SACOR, structural analysis based on the correlation matrix. 
needed to predict the real value of Desmanthus genotypes sp. for PEDL, leaf length and width; two cycles for stem diameter; and three cycles for number of leaves and PODL, if $\mathrm{R}^{2}=95 \%$ is considered (Table 4 ). To predict the actual height of the genotypes of Desmanthus sp. $\left(\mathrm{R}^{2}=95 \%\right)$, two evaluation cycles would be necessary with the PCACOR method and four cycles with the ANOVA 2 method, whereas three evaluations would be necessary with the other methods.

It was found that the increase in precision from 95 to $99 \%$ in relation to the prediction of the real value of the evaluations (Table 4), in all used methods, implied a considerable increase in the number of measurements for stem diameter, plant height, number of leaves, and PODL, making its application unfeasible. This information becomes important, especially at the beginning of a breeding program, in which a large number of genotypes are evaluated simultaneously and the selection of superior individuals must be made with greater accuracy (Torres et al., 2015), with the possibility of reducing the number of evaluations, costs, and the time required for the selection of promising genotypes.

In general, morphological, productive, and qualitative variability was observed among the genotypes of Desmanthus sp.; however, most of it was found in the first two groups formed, which implies that the genetic divergence among them was not high. For the studied characteristics, up to four evaluation cycles would be necessary for the selection process to have a $\mathrm{R}^{2}$ equal to $95 \%$ and for the superior or inferior behavior of the genotypes to be maintained. Moreover, the obtained estimates of the repeatability coefficient were of high magnitude, showing the reliability of the results.

\section{Conclusions}

1. There is a morphological, productive, and qualitative variability among the evaluated genotypes of Desmanthus sp., and forage yield, stem diameter, and leaf area index are the characteristics that contribute the most to the divergence among genotypes.

2. The estimates of the coefficients of repeatability and determination are of high magnitude for all variables by the different methods used.

3. Up to four evaluation cycles are required to predict the real value of Desmanthus sp. genotypes for stem diameter, peduncle length, plant height, leaf length and width, number of leaves, and pod length, considering a coefficient of determination of $95 \%$.

\section{Acknowledgments}

To Conselho Nacional de Desenvolvimento Científico e Tecnológico (CNPq), for financial support; and to Coordenação de Aperfeiçoamento de Pessoal de Nível Superior (Capes), for partial financial support (Finance Code 001).

\section{References}

APAC. Agência Pernambucana de Águas e Climas. Boletins Meteorológicos. Available at: <https://www.apac.pe.gov.br/ boletins>. Accessed on: Aug. 212019.

CALADO, T.B.; CUNHA, M.V. da; TEIXEIRA, V.I.; SANTOS, M.V.F. dos; CAVALCANTI, H.S.; LIRA, C.C. Morphology and productivity of "Jureminha" genotypes (Desmanthus spp.) under different cutting intensities. Revista Caatinga, v.29, p.742-752, 2016. DOI: https://doi.org/10.1590/1983-21252016v29n326rc.

CHAVES, G.G.; CARGNELUTTI FILHO, A.; CARINI, F.; KLEINPAUL, J.A.; NEU, I.M.M.; PROCEDI, A. Tamanho de parcela e número de repetições para avaliação de caracteres vegetativos em centeio. Revista Brasileira de Ciências Agrárias, v.13, e5563, 2018. DOI: https://doi.org/10.5039/agraria.v13i3a5563.

COSTA, J.C.; FRACETTO, G.G.M.; FRACETTO, F.J.C.; SANTOS, M.V.F.; LIRA JÚNIOR, M.A. Genetic diversity of Desmanthus sp accessions using ISSR markers and morphological traits. Genetics and Molecular Research, v.16, gmr16029667, 2017. DOI: https://doi.org/10.4238/gmr16029667.

CRUZ, C.D. Genes: a software package for analysis in experimental statistics and quantitative genetics. Acta Scientiarum. Agronomy, v.35, p.271-276, 2013. DOI: https://doi.org/10.4025/actasciagron.v35i3.21251.

CRUZ, C.D.; CARNEIRO, P.C.S.; REGAZZI, A.J. Modelos biométricos aplicados ao melhoramento genético. 3.ed. Viçosa: Ed. da UFV, 2014. 668p.

DINIZ, W.P. da S. Caracterização morfológica e nutricional de acessos de Desmanthus spp. submetidos a duas intensidades de corte. 2016. 81p. Dissertação (Mestrado) - Universidade Federal Rural de Pernambuco, Recife.

EDVAN, R.L.; CARNEIRO, M.S. de S.; SILVA, E.B. da; ALBUQUERQUE, D.R.; PEREIRA, E.S.; BEZERRA, L.R.; SILVA, A.L. da; ARAÚJO, M.J. de. Análise de crescimento da gliricídia submetida a diferentes manejos de corte. Archivos de Zootecnia, v.65, p.163-169, 2016. DOI: https://doi.org/10.21071/ az.v65i250.483.

GARDINER, C.; KEMPE, N.; HANNAH, I.; MCDONALD, J. PROGARDES ${ }^{\mathrm{TM}}$ : a legume for tropical/subtropical semi-arid clay soils. Tropical Grasslands - Forrajes Tropicales, v.1, p.78-80, 2013. DOI: https://doi.org/10.17138/TGFT(1)78-80. 
IUSS WORKING GROUP WRB. World Reference Base for Soil Resources 2014: international soil classification system for naming soils and creating legends for soil maps: update 2015. Rome: FAO, 2015. (FAO. World Soil Resources Reports, 106).

JANK, L.; BARRIOS, S.C.; VALLE, C.B. do; SIMEÃO, R.M.; ALVES, G.F. The value of improved pastures to Brazilian beef production. Crop \& Pasture Science, v.65, p.1132-1137, 2014. DOI: https://doi.org/10.1071/CP13319.

LATIMER JR., G.W. (Ed.). Official Methods of Analysis of AOAC International. 20 $0^{\text {th }}$ ed. Rockville: AOAC International, 2016. Official Method: 967.03 (dry matter) and 981.10 (crude protein).

MARTUSCELLO, J.A.; BRAZ, T.G. dos S.; JANK, L.; CUNHA, D. de N.F.V. da; LIMA, B.P. da S.; OLIVEIRA, L.P. de. Repeatability and phenotypic stabilization of Panicum maximum accessions. Acta Scientiarum. Animal Sciences, v.37, p.15-21, 2015. DOI: https://doi.org/10.4025/actascianimsci.v37i1.23206.

MUIR, J.P.; DUBEUX JR, J.C.B.; SANTOS, M.V.F. dos; MAPOSSE, I.C.; PITMAN, W.D.; BUTLER, T.J. Challenges to domesticating native forage legumes. Tropical Grasslands - Forrajes Tropicales, v.2, p.94-96, 2014. DOI: https://doi.org/10.17138/TGFT(2)94-96.

MUIR, J.P.; SANTOS, M.V.F.; CUNHA, M.V. da; DUBEUX JÚNIOR, J.C.B.; LIRA JÚNIOR, M. de A.; SOUZA, R.T. de A.; SOUZA, T.C. de. Value of endemic legumes for livestock production on Caatinga rangelands. Revista Brasileira de Ciências Agrárias, v.14, e5648, 2019. DOI: https://oi.org/10.5039/agraria.v14i2a5648.

PATIL, P.V.; PATIL, M.K.; SALUNKE, V.M. Dry matter intake and growth performance in Osmanabadi goat kids maintained on DHN6 grass, Dashrath grass and Jowar straw. Journal of Entomology and Zoology Studies, v.8, p.1857-1858, 2020.

QUEIROZ, I.V. de. Ocorrência e germinação de sementes de Desmanthus sp. coletadas no semiárido Pernambucano. 2012. 65p. Dissertação (Mestrado) - Universidade Federal Rural de Pernambuco, Recife.
RESENDE, M.A.V. de; FREITAS, J.A. de; LANZA, M.A.; RESENDE, M.D.V. de; AZEVEDO, C.F. Divergência genética e índice de seleção via BLUP em acessos de algodoeiro para características tecnológicas da fibra. Pesquisa Agropecuária Tropical, v.44, p.334-640, 2014. DOI: https://doi.org/10.1590/ S1983-40632014000300006.

RESENDE, M.D.V. de. Genética quantitativa e de populações. Viçosa: Suprema, 2015. 463p.

RODRIGUES, E.V.; DAHER, R.F.; GRAVINA, G. de A.; VIANA, A.P.; ARAÚJO, M. do S.B. de; OLIVEIRA, M.L.F.; VIVAS, M.; MENEZES, B.R. da S.; PEREIRA, A.V. Repeatability estimates and minimum number of evaluations for selection of elephant-grass genotypes for herbage production. Bioscience Journal, v.36, p.30-41, 2020. DOI: https://doi.org/10.14393/BJv36n1a2020-42075.

SANTOS, M.V.F. dos; CUNHA, M.V. da; DUBEUX JR, J.C.B.; FERREIRA, R.L.C.; LIRA JR, M. de A.; OLIVEIRA, O.F. de. Native shrub-tree legumes of tropical America with potential for domestication. Legume Perspective, v.17, p.33-35, 2019.

SONAWANE, A.S.; DESHPANDE, K.Y.; RATHOD, S.B.; SHELKE, P.R.; NIKAM, M.G.; GHOLVE, A.U. Effect of feeding Hedge lucerne (Desmanthus virgatus) on intake, growth performance and body condition score in growing Osmanabadi goats. Indian Journal of Animal Sciences, v.89, p.881-884, 2019.

TOEBE, M.; CARGNELUTTI FILHO, A.; MELlO, A.C.; SOUZA, R.R. de; SOARES, F. dos S.; SILVA, L.S. da; SEGATTO, A. Plot size and replications number for triticale experiments. Ciência Rural, v.50, e20200222, 2020. DOI: https://doi.org/10.1590/0103-8478cr20200222.

TORRES, F.E.; VALLE, C.B. do; LEMPP, B.; TEODORO, P.E.; SANTOS, A. dos; SILVA JUNIOR, C.A. da. Minimum number of measurements for accurate evaluation of qualitative traits in Urochloa brizantha. Journal of Agronomy, v.14, p.180-184, 2015. DOI: https://doi.org/10.3923/ja.2015.180.184. 